НАУКОВИЙ ВІСНИК

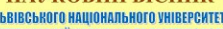
РИНАРНОї МЕДИЦИНИ ТА БОТЕКНОЛО імені с.3. гжицького Scientific messenger of Livi National Uniersity
Veterinary Medicine and Biotechnologies

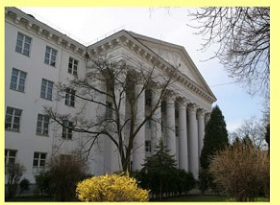

СЕРІЯ “ЕКОНОМІчн НАУКИ"

Том 21 № 93 2019

Науковий вісник Львівського національного університету ветеринарної медицини та біотехнологій імені С.3. Гжицького. Серія: Економічні науки

\author{
Scientific Messenger of Lviv National University \\ of Veterinary Medicine and Biotechnologies. \\ Series: Economical Sciences
}

UDC 338.439.5

\title{
To the question of tendency and conjuncture of the meat market
}

\author{
A.V. Grymak
}

Stepan Gzhytskyj National University of Veterinary Medicine and Biotechnologies, Lviv, Ukraine

Article info

Received 03.09.2019

Received in revised form 03.10 .2019

Accepted 04.10.2019

Stepan Gzhytskyi National University of Veterinary Medicine and Biotechnologies Lviv, Pekarska Str., 50, Lviv, 79010, Ukraine.

Tel.: +38-050-811-20-52 E-mail: Allagrimak@gmail.com
Grymak, A.V. (2019). To the question of tendency and conjuncture of the meat market. Scientific Messenger of Lviv National University of Veterinary Medicine and Biotechnologies. Series: Economical Sciences, 21(92), 13-16. doi: 10.32718/nvlvet-e9303

With regard to the problem under the study, it is worth pointing out facts new to Ukraine, which have already been recognized by the market economy state. First of all, that the functioning of the market is closely linked to the deepening of the social division of labor, industrial relations, and that it (the market) has evolved into a coherent system of economic relations between the subjects. As a consequence, the market covers the process of circulation of goods and services under the scheme: supply-intermediarydemand, and market economy - production-distribution-exchange-consumption. Scientists O.V. Sholudko, O.A. Bitter, Z.P. Berezovsky argue that in order to shape the market for beef cattle, the implementation of the supply of goods must be expressed through the so-called exchange infrastructure: exchanges, wholesale markets, auctions, trading houses, fairs, branded shops, retail, urban markets. In our opinion, this list of infrastructure components misses out on such components as the spontaneous markets on the streets of big cities and resort centers, which actually exist and will not disappear in the near future. This is counteracted by objective factors, the most important of which is the struggle of the small food producer for survival. Specifically to the topic, it should be noted that, under the existing natural, climatic and economic conditions, it is relevant for the region, and Lviv region in particular, to create on the market, in accordance with the components of market infrastructure, conditions for increasing supply of beef in order to meet the demand for these products. At the same time, it is economically important to work simultaneously to ensure the production of competitive, quality products that would be in demand among consumers. The saturation of the domestic market for meat and products of its various producers is a confirmation of the high demand for these products. Therefore, the justification of effective management of beef cattle is to take advantage of market relations and marketing research in the production of competitive products. And, at the expense of livestock products, a person satisfies 40-50\% of their need for food. In particular, a person should consume at least 100 grams of protein daily, including 70 grams of animal origin, for nutrition. Providing the population with food is perhaps the most responsible problem of the economy and politics.

Key words: beef cattle, market infrastructure, marketing, competitiveness, quality, food.

\section{До питання оцінки тенденцій і кон'юнктури ринку м'ясного скотарства}

\author{
А.В. Гримак
}

Львівський національний університет ветеринарної медицини та біотехнологій імені С.3. Гжицького, м. Львів, Україна

Стосовно досліджуваної проблеми варто вказати на факти, нові для України, яка вже фактично визнана державою з ринковою економікою. Насамперед, щчо функиіонування ринку тісно пов 'язане з поглибленням суспільного поділу праці, виробничих відносин і щзо він (ринок) переріс у иілісну систему економічних відносин між суб'єктами. Як наслідок, ринок охоплює процес обігу товарів і послуг за схемою: пропозичія-посередник-попит, а ринкова економіка - виробництво-розподіл-обмін-споживання. Вчені О.В. Шолудько, О.А. Біттер, З.П. Березівський стверджують, щчо для формування ринку м'ясного скотарства втілення пропозиції товару повинно виражатись через так звану обмінну інфраструктуру: біржі, гуртові ринки, аукціони, торгові доми, ярмарки, фірмові магазини, роздрібну торгівлю, міські ринки. На нашу думку, в цььому переліку складових інфраструктури упущено таку 
складову, як стихійні ринки на вулицях великих міст і курортних иентрів, які реально існують і в найближчій перспективі не зникнуть. Цьому протистоять об'єктивні чинники, серед яких найважливіший - боротьба дрібного товаровиробника продуктів харчування за виживання. Конкретно до теми, варто зазначити, щуо за наявних природно-кліматичних та економічних умов актуальним для регіону, і Львівської області зокрема, є створення на ринку, відповідно до складових ринкової інфраструктури, умов для підвищення пропозицій яловичини з метою задоволення попиту на дану продукиію. При цььому економічно важливо паралельно працювати над забезпеченням виробництва конкурентоспроможної, якісної продукиіі, яка б користувалася попитом у споживачів. Насичення внутрішнього ринку м'ясом і продуктами його переробки різних виробників є підтвердженням високого попиту на цъю продукцію. Тому, виправданою умовою ефективного господарювання у м'ясному скотарстві є використання переваг ринкових відносин і маркетингових досліджень у виробництві конкурентоспроможної продукиії. Причому, за рахунок тваринницької продукиії людина задовольняє 40-50\% своєї потреби у продуктах харчування. Зокрема, для повноцінного харчування людина щзоденно повинна споживати як мінімум 100 г білка, в т. ч. 70 г тваринного походження. Забезпечення населення продуктами харчування $\epsilon$ чи не периочерговим завданням економіки і політики.

Ключові слова: м'ясне скотарство, ринкова інфраструктура, маркетинг, конкурентоспроможність, якість, продукти харчування.

\section{Ветуп}

Ринок м'ясного скотарства функціонує в умовах фінансової нестабільності сільськогосподарських підприємств. Це позначається на формуванні організаційно-економічного механізму ринку як у частині виробництва та поставки готової продукції м'ясного скотарства, так і взаємовідносин партнерів. Як наслідок, вплив таких факторів підсилює значення досліджень ефективності виробництва м'яса ВРХ, встановлення наявних тенденцій і чинників, що їх спричинили. За цих умов саме маркетинг виступає одним 3 основних механізмів, який забезпечує реальність у досягненні мети усім суб'єктам ринку м'ясного скотарства. Результати маркетингових досліджень $є$ важливими для сільськогосподарських виробників сировини, зокрема у збалансованості м'ясних ресурсів, розвитку результативної співпраці 3 переробними підприємствами. I що є важливим - це вивчення кон'юнктури ринку м'ясного скотарства, що сприятиме виявленню стримуючих чинників розвитку галузі для аналізу і формування цілісної системи функціонування всіх ланок діяльності суб'єктів м'ясопродуктового підкомплексу, спрямованої на випуск конкурентоспроможної продукції, яка користується попитом.

\section{Матеріал і методи досліджень}

Дослідження за темою статті проводилися з використанням методів економічного аналізу процесів на ринку продукції м'ясного скотарства, маркетингових досліджень, статистичних з узагальненням прогресивного досвіду.

\section{Результати та їх обговорення}

Щодо оцінки кон'юнктури ринку стосовно діяльності сільськогосподарських i переробних підприємств, які належать до м'ясопродуктового підкомплексу, то іiї варто розглядати як механізм аналізу та інформаційного моделювання ринку за його складовими. Доцільно при цьому використовувати маркетингові дослідження, які забезпечують не лише повноцінну інформацію про ринок м'ясного скотарства, а й сприяють раціональному розподілу затрат на всіх етапах виробництва продукції та іiі обігу. М'ясопереробні підприємства “Дрогобицький м'ясокомбінат”, ТзОВ “Барком” (Родинна ковбаска), ТзОВ “Білаки” та інші, в структурі яких функціонують маркетингові, аналітичні служби, володіють інформацією про ринок збуту продукції, споживачів, кон'юнктуру ринку. Співпраця названих підприємств iз сільськими товаровиробниками різних форм власності на різних умовах, в т. ч. договірних, дозволяє їм збалансовано вести виробництво продукції, забезпечувати себе сировиною.

Варто зазначити, що всі підприємства м'ясопродуктового підкомплексу мають свої особливості та переваги.

Щодо переваг, то вони є важливим показником під час визначення конкурентоспроможності продукції конкретного виробника на ринку. Економічна оцінка переваг одного підприємства перед іншим, яке випускає таку саму продукцію, розглядає їх як внутрішні й зовнішні. Внутрішні конкурентні переваги стосуються здебільшого виробничих затрат, їх економії, ефективності (рентабельності) виробництва, відповідності його технології сучасним вимогам. До зовнішніх же переваг належать:

- розташування підприємства, транспортний зв'язок з ним;

- асортимент продукції підприємства;

- рівень цін, можливість знижок;

- швидкість і якість обслуговування;

- організація контролю якості продукції;

- екологічна чистота продукції.

Підприємства м'ясопродуктового підкомплексу Львівської області мають значний набутий досвід випуску конкурентоспроможної продукції. Разом 3 тим, аналіз їх можливостей підтверджує, що недостатньо лише природних, екологічних чи соціальних чинників у створенні конкурентоспроможної продукції. У досягненні цієї мети варто постійно приділяти увагу матеріально-технічній базі підприємств, iї удосконаленню, так само як і технології виробництва продукції та кваліфікації працівників і їх відповідальності за дотриманням стандартів і контролювання якості готової продукції.

Оцінювання конкурентоспроможності продукції м'ясного скотарства на ринку лише показниками іiі виробництва буде неповною інформацією про ситуацію на ринку. Для повної й об'єктивної інформації про кон'юнктуру ринку, конкурентоспроможність продукції не обійтись без оцінки механізму поставок i 
розміщення продукції на ринку, ії асортименту, якості i, звичайно, ціни. Адже конкурентоспроможність продукції - це не тільки ії асортимент, а й порівняльна оцінка своєї продукції з продукцією конкурентів, насамперед за якістю і ціною.

За роки реформ відбулись суттєві зміни, в т. ч. й організаційні, спрямовані на переорієнтацію економічної поведінки суб' єктів господарювання. До найістотніших можна віднести:

- забезпечення незалежності товаровиробників у виробничій і збутовій діяльності;

- налагодження багатоканальної системи реалізації сільськогосподарської продукції;

- створення відповідної нормативно-правової бази, яка б дозволила регламентувати інтеграційні процеси в рамках АПК;

- відновлення державного стимулювання збуту через механізми поставок на переробку м'ясосировини.

Однак, незважаючи на певні заходи, стійких, стабільних господарських зв'язків, як і надійного партнерства між виробниками, торгівлею і споживачами не склалось. Закріпилась негативна тенденція скорочення поголів’я тварин (табл. 1).

\section{Таблиця 1}

Динаміка чисельності поголів'я великої рогатої худоби, тис. голів

\begin{tabular}{ccc}
\hline \multirow{2}{*}{ Роки } & \multicolumn{2}{c}{ Поголів'я великої рогатої худоби } \\
\cline { 2 - 3 } & усього & у т. ч. корови \\
\hline 2015 & 210,3 & 136,7 \\
2016 & 203,4 & 129,7 \\
2017 & 195,3 & 121,3 \\
2018 & 184,0 & 112,6 \\
2019 & 170,9 & 103,6 \\
2019 до 2015, \% & 81,2 & 75,8 \\
\hline
\end{tabular}

Джерело: підготовлено А.В. Гримак за даними Головного управління статистики Львівської області

За умов різкого, загального зменшення поголів'я великої рогатої худоби все-таки більша його частка зосереджена в селянських господарствах, які фактично стали основними постачальниками м'ясної продукції на ринок, хоча це не компенсує рівнів стабільного забезпечення населення високоякісним м'ясом яловичини за доступними цінами, а переробної промисловості сировиною у достатній кількості. Це не сприяє нарощуванню запасів м'ясних ресурсів яловичини, як і до приведення цін у відповідність гарантованої купівельної спроможності споживачами.

До показників, які використовуються при вивченні кон'юнктури ринку м'ясного скотарства, належать загальноекономічні показники, зокрема внутрішнього i зовнішнього товарообігу, кредитно-грошової сфери, сфери переробки, обсягу капіталовкладень, ціни тощо (Sabluk et al., 1996). Саме ціни відіграють чи не головну роль при оцінці кон'юнктури ринку. Для сільгоспвиробників життєво важливо змінити і сформований не на їх користь диспаритет цін, ослабити ризики, пов'язані із залежністю від природо-кліматичних умов, стихійності ринку продукції м'ясного скотарства. Вирівняти ситуацію, а це вже підтверджено і практикою, може створення інтегрованих структур, що сприятиме: об'єднанню фінансового, аграрного, промислового i торговельного капіталу, консолідації потенційних можливостей підприємств у процесі виробництва, переробки, зберігання і реалізації продукції, ослабленню фінансових ризиків, вирівнюванню економічних умов для підприємств за рахунок збалансування механізму перерозподілу доходів, скорочення кількості посередницьких ланок в поставках м'ясної сировини і реалізації готової продукції.

Важливо, що розвиток інтегрованих формувань сприятиме ефективному функціонуванню ринку м'ясного скотарства i підвищенню прибутковості сільськогосподарських виробників, а все це суттєво, позитивно позначиться і на кон'юнктурі ринку галузі.

Аналіз праць ряду дослідників свідчить, що оцінити рівень ринкової кон'юнктури можливо на основі оцінки низки показників, а саме - це вивчення ринкової пропозиції, рівнів цін та попиту, які вказують на стан і дієвість економічних ринкових механізмів, зокрема i конкурентоспроможність продукції м'ясного скотарства і послуг (Komarnyc'ka, 2002; Grymak, 2005; Tryn'ko \& Grymak, 2009). Ринок є узагальнюючим показником оцінки функціонування м'ясопродуктового підкомплексу і тваринництва взагалі, який вказує на недосконалість ринкової інфраструктури, в якій свою переважаючу активність проявляють посередницькі структури, що виходять зі своїх інтересів і пропонують сільгоспвиробникам свої умови збуту сировини, продукції та іiі реалізації за цінами, які не покривають навіть витрат виробників і не стимулюють до отримання прибутків.

Реально існуючий взаємозв'язок виробництва, потреб населення у м'ясних продуктах і платоспроможного попиту характеризує стан ринку продукції м'ясного скотарства. Водночас, сам попит на м'ясну продукцію не може існувати відокремлено від пропозиції і проявлятися в надлишку чи нестачі продукції або ж бути збалансованими. Результати досліджень підтверджують, що на ринку продукції м'ясного скотарства найслабшою ланкою є попит, що спричинено порівняно низькою платоспроможністю населення. А це призводить до вимушеної заміни якісних, дорожчих продуктів, дешевшими та змінами в раціоні харчування на користь свинини i, особливо, м'яса птиці.

Щодо доведення готової продукції до споживача, а це $\epsilon$ в пріоритеті діяльності м'ясопереробних підприємств, окремі з них (ТзОВ “Барком”, Львівська обл.), мають власну торговельну мережу, яка забезпечує:

1. Необхідні обсяги й асортимент якісної продукції в обігу продукції від виробника до споживача;

2. Врахування платоспроможності споживачів;

3. Зменшення втрат готової продукції.

Без сумніву, такий підхід позитивно позначається і на кон'юнктурі ринку продукції м'ясного скотарства, яка, до речі, в області склалась і відображає взаємозалежність як від рівня виробництва сировини, так i готової продукції - яловичини, телятини з відповід- 
ним рівнем цін, який є в прямій залежності від заробітної плати, тобто платоспроможності.

\section{Висновки}

1. Невід'ємною умовою ефективного господарювання в м'ясному скотарстві $є$ використання переваг ринкових відносин і результатів маркетингових досліджень у виробництві конкурентоспроможної продукції, що дозволить сформувати на ринку продукції конкурентне середовище і оптимізувати його структуру. Інформація про стан ринку продукції м'ясного скотарства, його інфраструктуру, перспективу розвитку важлива для прийняття рішень на всіх рівнях: як підприємницькому, так і державному.

2. Найбільш вираженою нестабільністю відносин між переробними підприємствами і сільськогосподарськими товаровиробника є диспаритет цін на сировину і готову продукцію, сформований не на користь сільських виробників. Як наслідок, ріст цін на продукцію переробки за останні 5 років перевищував ціни на живу вагу м'ясної худоби у середньому в 4-5 разів, що призвело до збитковості м'ясного скотарства. Це відповідно позначилось і на суттєвому скороченні поголів'я великої рогатої худоби на відгодівлі у всіх категоріях господарств.

3. Сільськогосподарські переробні підприємства, які є суб'єктами ринку продукції м'ясного скотарства, мають свої особливості, які необхідно приводити у відповідність до регламентуючих нормативних документів. У цьому значна роль відводиться маркетингу як механізму, що забезпечує об'єктивність у досягненні мети: вивчення потенційних споживачів і замо- вників на продукцію, аналіз їх запитів і вимог, можливостей виробників; оцінку асортименту й обсягу замовлень; роботу з контрактами.

Перспективи подальших досліджень. Продовжувати дослідження економічних факторів зі створення передумов щодо подолання проблем в галузі м'ясного скотарства, зокрема виробництва і поставок на ринки якісної, конкурентоспроможної продукції.

\section{References}

Grymak, A.V. (2005). Marketyngovi doslidzhennja konkurentospromozhnosti na rynku m'jasa ta m'jasoproduktiv. Zb. nauk. pr. Formuvannja rynkovoi' ekonomiky. Spec. vyp.: suchasni problemy teorii' i praktyky marketyngu. K.: KNEU, 377-383 (in Ukrainian).

Komarnyc'ka, O.P. (2002). Formuvannja rynku velykoi' rogatoi' hudoby. Ekonomika APK, 12, 103-105.

Sabluk, P.T., Bojko, V.I., \& Lobajev, M.G. (1996). Rynok prodovol'stva: problemy formuvannja i rozvytku. K: IAE UAAN (in Ukrainian).

Sholud'ko, O.V., Bitter, O.A., \& Berezivs'kyj, Z.P. (2004). Rynok produkcii' skotarstva: problemy i perspektyvy. L'viv: NVF "Ukrai'ns'ki tehnologii" (in Ukrainian).

Shust, O.A. (2011). Stan i tendencii' rozvytku rynku m'jasa v Ukrai'ni. Visnyk agrarnoi' nauky, 5, 68-70 (in Ukrainian).

Tryn'ko, R.I., \& Grymak, A.V. (2009). Rynok produkcii' m'jasnogo skotarstva: stan, perspektyvy rozvytku. Monografija. L'viv. TzOV "Liga Pres" (in Ukrainian). 